\title{
Mountain hazard susceptibility and livelihood security in the upper catchment area of the river Beas, Kullu Valley, Himachal Pradesh, India
}

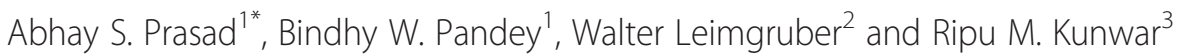

\begin{abstract}
Background: Natural hazards have had significant impacts on life, livelihood and property in the mountain regions. Hazards identification in high mountain areas involved intensive and lengthy fieldwork and mapping with the interpretation of landforms and its related hazards, compulsion of increasing intensity of land-use and careless application of technology leading to further land degradation. Frequent occurrences of hazards such as landslides, snow avalanche, floods and other types of mass wasting are becoming common features in mountainous regions.

Results: Himalayan watershed has undergone a most dynamic change in land-use owing to the rapid increase in the population. The change in biophysical systems posed the direct bearing on the hydrological regime of Beas River. The peoples' perceptions regarding origin of hazards and techniques of control to the hazards showed that indigenous and lowland communities are more susceptible to hazards. Deforestation, slope cutting, construction of roads and heavy rainfall were high responsible factors resulting frequent landslides and soil erosion. Hazards cannot be avoided, however their disastrous pursuits can be lessened through pro-active uses of a variety of planning measures, infrastructure and risk transfer mechanism. Afforestation, embankment, better drainage techniques on slope, check on urban sprawl, and ecotourism are effective techniques to offset the local hazards and livelihood vulnerabilities.
\end{abstract}

Conclusion: Owing to the typical geomorphic setting such as high relief variations, thick forest cover, presence of glacier and glacial lakes along the higher reaches, the Beas River is prone to cloudbursts, flash floods, forest fires, landslides and mass movement. The sustainable livelihood of Beas River may best be bestowed by enhanced landuses aided by technologies of bio-engineering, denaturalization of degraded mountain geosystem and resilience for changes.

Keyword: Landslide, Cloudburst, Flash flood, Forest fire, Sustainable livelihood, Mountain tourism and sustainable development

\section{Background}

Himachal Pradesh is exposed to frequent natural disasters such as earthquake, landslides, cloudburst, avalanches, flash floods etc. with varying intensities. Though, landslides are considered as one of the most frequent it causes a large scale disruption of natural resources, economic

\footnotetext{
* Correspondence: abhaydse@hotmail.com

'Department of Geography, Delhi School of Economics, University of Delhi, New Delhi, India

Full list of author information is available at the end of the article
}

valuables and human lives. In the recent years, growing population and expansion of human circumference on fragile land or hazardous areas have largely increased impact of natural disasters in the Lesser Himalaya region of India. Particularly, the Lesser Himalayan states are more vulnerable than other hilly part of the country. The Himalayan ranges are formed of younger geological formation, and tectonically very active. Large number of landslides occurs every year and causes loss of lives, extensive damage to properties and as well as natural resources. Often, it 
becomes more dangerous sometime by killing human beings. In these areas, how to minimize impact of landsliding is very difficult as required high costly measures of controlling natural hazards through engineering structures and rational land-use planning. It was felt that due to proindustrialized policy of government large number of industry has been set-up in the area. This has two-way impacts. Firstly, the change in land-cover and modification of slope geometry destabilize slopes and secondly it requires other allied infrastructures, such as transportation, power, raw materials etc. (Pandey 2014).

Each and every part of the world is more or less susceptible to natural calamities, the Himalayas is more complex due to its dynamic geomorphology/geosystem (Rawat 2013) and seasonal hydro-meteorological conditions experience very frequent natural disasters, especially water induced hazards (Nibanupudi and Shaw 2015). Climate change and land-use degradation accelerate water induced hazards such as flash floods, riverine floods, erosion, landslides during the monsoon period, and droughts in non-monsoon periods. The geo-dynamically active Himalayan terrain is being deforested at the rate of $0.36 \mathrm{~km}^{2}$ year ${ }^{-1}$ (Rawat and Pant 2007). Several anthropogenic factors namely poorly managed agriculture, forest fires, overgrazing, and substandard construction of roads and buildings may accentuate the process (Bhasin et al. 2002). Increasing population and demand of land for agriculture have resulted in acute pressure on the land in the watershed of the Lesser Himalaya (Rawat et al. 2010, 2012).

Floods, landslides, soil erosion, rock falls, debris flows, accelerated erosion and snow avalanches are common hazards in Kullu Valley. Population growth and economic development, especially since 1990, have increased the vulnerability to hazards, and living with the risk of natural hazards is part of everyday life (Pandey 2002). Landslides are one of the most common natural hazards; they can be disastrous with massive destructions of life and property and may also lead to large scale landscape transformations. There are records of several massive landslides (Punjab Government 1926; Gardner 2002) occurring in the past that caused massive damage to property and infrastructure along with human casualties in the study area.

In Lesser Himalaya, mountain tourism is of particular concern because it is frequently espoused as a means of community development that can provide alternative livelihood opportunities, diversify local economies, promote population growth, and address problems of poverty and livelihood security (Singh 1989; Sharma 1998; Sinclair and Ham 2000). In this paper, we characterized and monitored hazards and sustainable development initiatives in Beas River valley (Kullu valley, Himachal Pradesh). In particular we applied a novel approach in identification, characterization and mapping of hazards particularly flooding, erosions, debris-flows and various types of slope failures or landslides as hazards and identified vulnerable issues and suggest the adaptation techniques for sustainable development.

The adaptation and mitigation policy for livelihood security is devised based on climatic vulnerability assessment and deals with coping strategies of local communities in the face of increasingly frequent and extreme climatic events (Paavola and Adger 2005; Eriksen and O’Brien 2007). The vulnerability and adaptation assessment suggests a key role for targeted assistance in helping the local community to adapt to climate change and disaster risk reduction in mountain regions (Smit and Pilifosova 2001; Huq 2007; Lemos et al. 2007) and instead of more bottomup forms of assistance, the adaptive capacities and flexible governance structures to be emerged (Ostrom 2007; Hahn et al 2009; Wisner 2010). The sustainable livelihood security framework may be suitable for assessing local level vulnerability and adaptive capacity through analyzing the status of five capital assets such as financial, human, social, physical and natural (Chambers and Conway 1992).

The rural mountain communities, primarily dependent on natural resources, are highly vulnerable to multiple stresses and hazards including intensification of commercial activities and infrastructure development (Jodha 2005). The limited livelihood options, further aggravates the situation by exposing these communities to the threats of marginalization and poverty (Jodha 2005; Ratz 2000).

\section{Site description}

Study area, the Upper Beas River Basin is situated in the northern part of Kullu valley, Himachal Pradesh, Lesser Himalaya, India. The Kullu district is located in the Pir-Panjal range of the western Himalayas in Himachal Pradesh, India bounded by Lahul, Spiti, and Kangra districts to the north and north-east, to the east and south-east by Kinnaur and Shimla districts and in the south-west by Mandi district. It covers an area of $122 \mathrm{~km}^{2}$ and spans in the Lesser Himalayas between $31^{\circ} 20^{\prime}$ and $32^{\circ}$ $26^{\prime} \mathrm{N}$ latitudes and $76^{\circ} 59^{\prime}$ and $77^{\circ} 50^{\prime} \mathrm{E}$ longitudes, India (Burrard and Hayden 1933). The Kullu valley itself constitutes the upper reaches of the Beas River, is about $90 \mathrm{~km}$ long, from Larji in the south to Rohtang Pass in the north, and is relatively broad at its base (up to $3 \mathrm{~km}$ ). Elevations in Kullu district stretch from about $1000 \mathrm{~m}$ to more than $6000 \mathrm{~m}$, with the terrain comprising deeply incised river valleys interspersed with high mountain ridges and massifs of very high, glacier mountain peaks (Fig. 1, Administrative divisions of study area and Fig. 2, Study area, Beas River, Kullu Valley, Himachal Pradesh).

The Beas River rises in the Pir-Panjal range of Central Himachal Pradesh near Rohtang Pass, about $51 \mathrm{~km}$ north of Manali town. Together with Chandra-Chenab, 


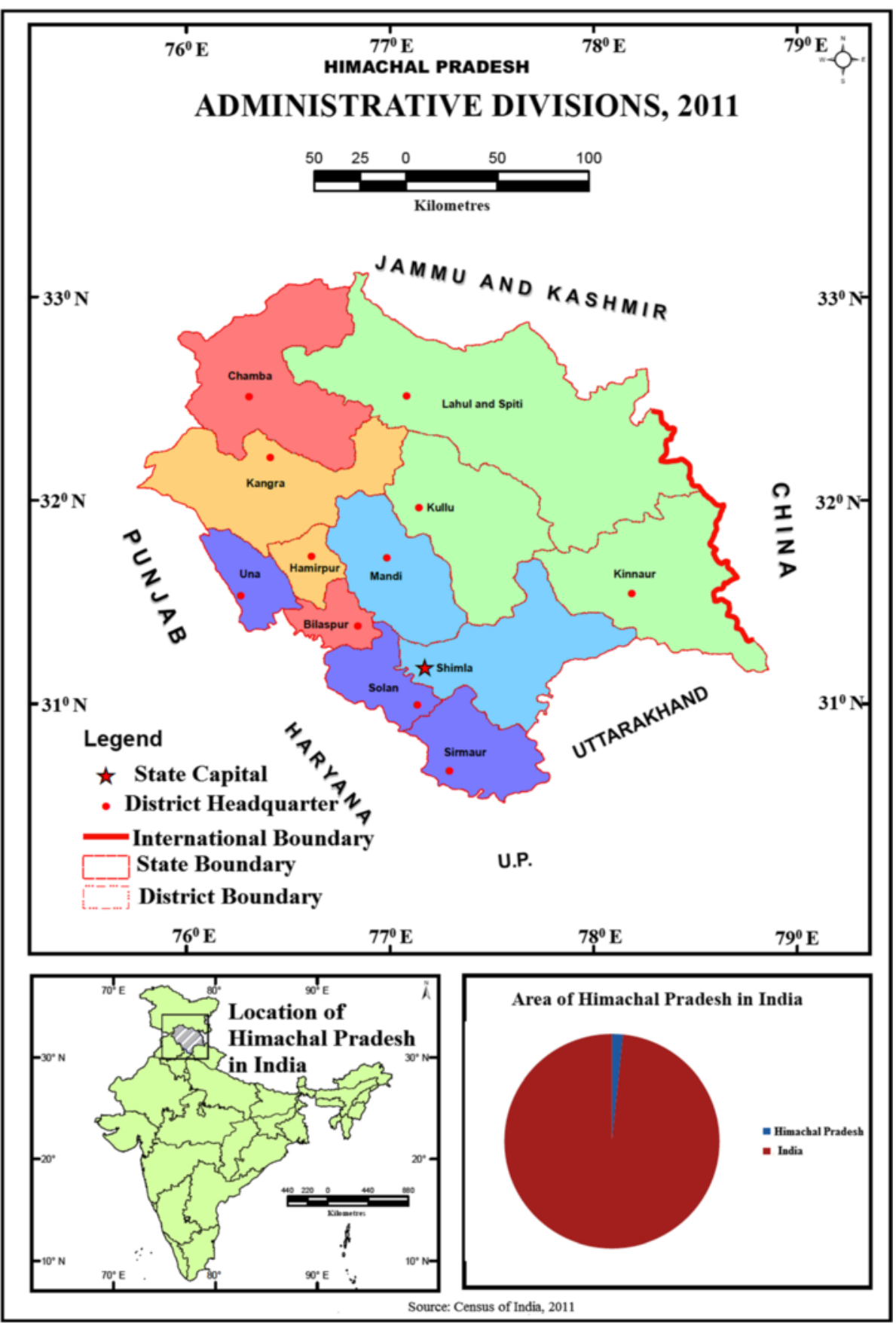

Fig. 1 Administrative division, Himachal Pradesh

Ravi and Sutlej Rivers which also drain parts of Himachal Pradesh, the Beas River serves as a water source for economic development and livelihood sustainability in Himachal Pradesh, Punjab and Rajasthan (Fig. 3, Drainage System). In its upper reaches, it flows north to south or transversely through the Himalayan ranges. In its lower reaches, it is considered as one of the perennial Himalayan Rivers cutting a deep gorge through the southern Himalayan ranges (Pandey 2010). Before it reaches Marhi (a seasonal settlement), it is like a tributary fed by the melted snow of the Rohtang Pass, India. Further, it reaches Rahla (another seasonal settlement) where it plunges into deep gorge to be temporarily lost to view. Then rushing in between mountains lined with pine trees, it reaches Manali town. Only south of Manali, the Beas becomes wide and gentle in gradient. There are more than hundreds of small and big streams joining Beas within the stretch of $51 \mathrm{~km}$ between Rohtang pass 


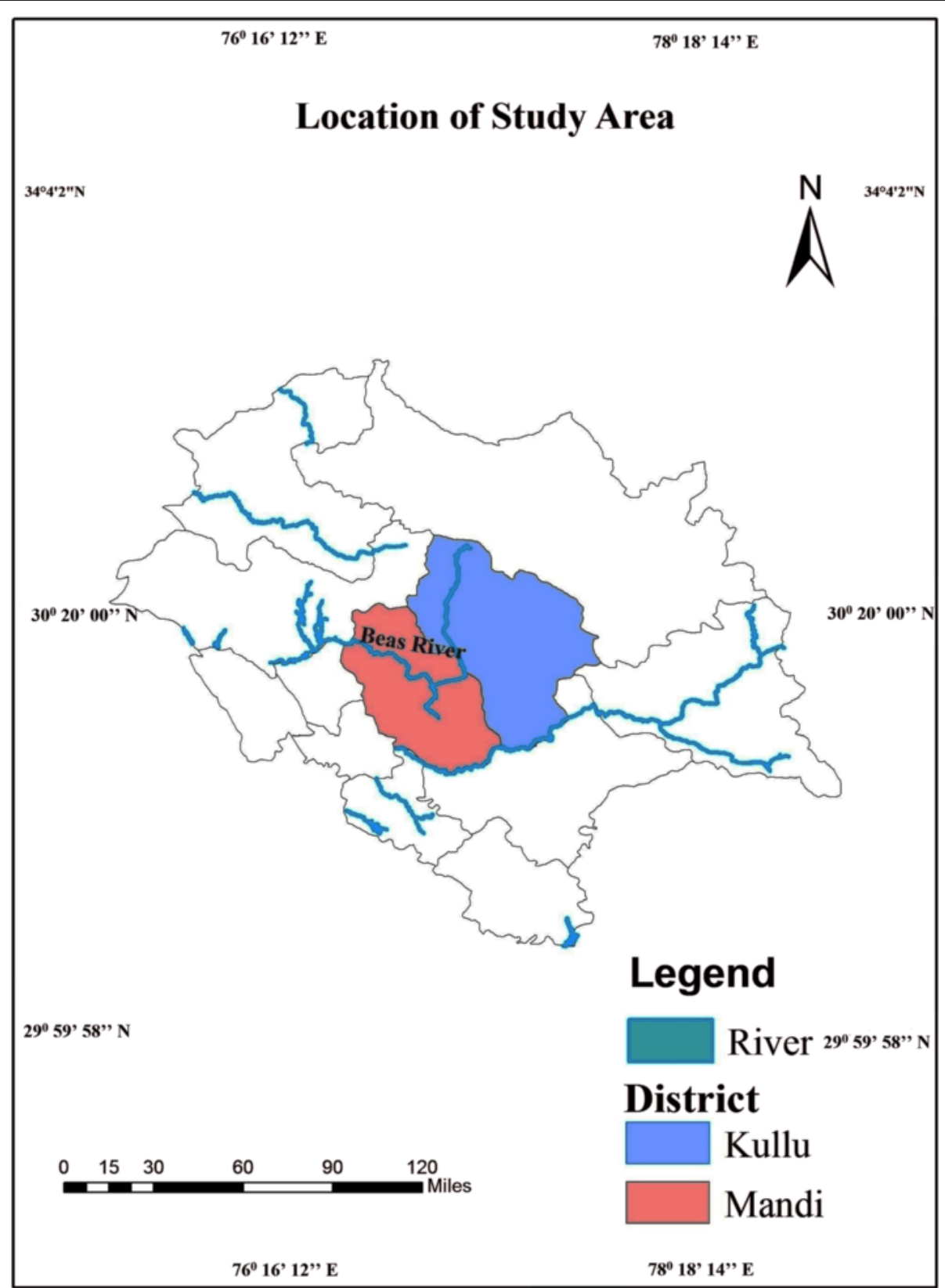

Fig. 2 Study area, Beas River, Kullu Valley, Himachal Pradesh

to Manali (Pandey and Prasad 2014). Most of the streams are snow fed and act as perennial source of water for local communities.

\section{Methods}

Both primary and secondary data were utilized for analysis the vulnerability and adaptation attributes. Secondary data were collected from satellite images to map forest-cover, water bodies, land-use/land-cover and drainage pattern. Topographical maps at the scale of 1:250,000 were obtained from the survey of India and National Atlas \& Thematic
Mapping Organization (NATMO), Delhi to map physical characteristics, drainage system, infrastructure facilities, and geological map. Construction and tourism related data were taken from Tourism Development Corporation and Public Work Department, Himachal Pradesh.

Perception of local community regarding sustainability and hazard occurrences and management was recorded through reconnaissance survey and semi-structured questionnaire. A total of 200 households were selected for interviews in Kullu valley. Simple random sampling technique was used for categorization in collecting the 


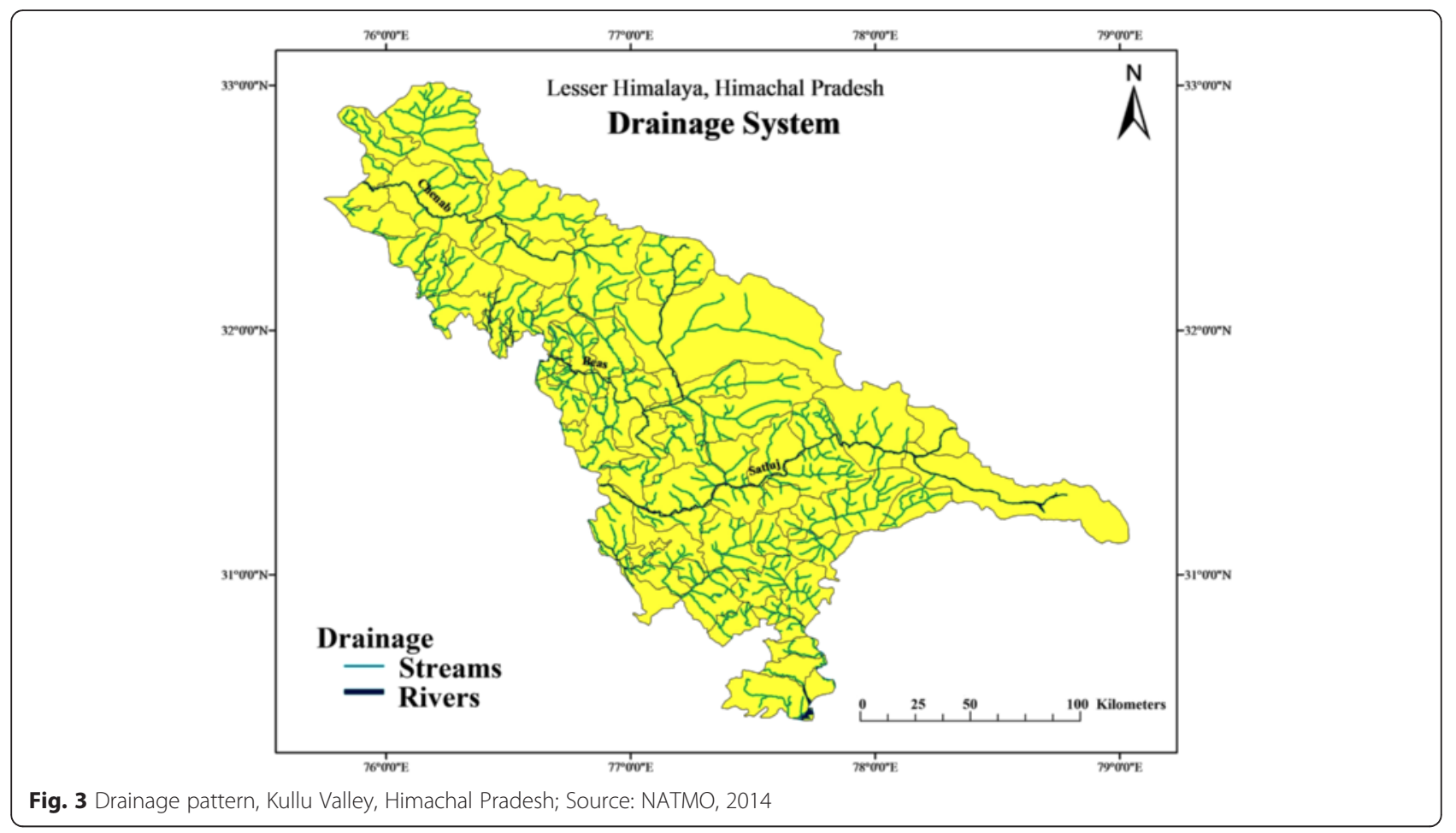

samples. The hamlets were divided into four groups according to their altitude and proximity to the river. The clustering of villages was carried out on the basis of landholdings of the villagers, education, caste/ethnicity and the economic status. All the cross-sections of the society available in the study area were covered while completing the sampling. To accumulate the sound data, the villages were sampled keeping in view the spatial distribution of hazards and their intensity including the size of the villages in terms of both the area as well as population.

The questionnaire was specific to cloudburst and extreme rainfall events, hazards, flash floods, landslide, deforestation, slope cutting and tourism and their management. Informal interviews and discussions with local people and officials provided information about the locations of prior events. History recall and historical timeline methods were used for assessment of archive, historical documents, photos and records.

In this communication, Likert scale was employed for analyzing the peoples' perception regarding the origin, trend, frequency, magnitude and the techniques of control the hazards in upper catchment area of Beas, Kullu valley. This was also subjected for analyzing and identifying the issues of eco-development practices within the village community. It was also designed to determine and identify the opinion of the subject. In Likert scale categories have been assigned into 5 responses. Usually, the most negative responses are numerated into a given numerical values of 1 , whilst the most positive response has a numerical values of 5 such as strong agree (5), agree (4), uncertain (3), disagree (2), strongly disagree (1) (Likert 1932).

\section{Hazard assessment}

The analysis was based on maps from Survey of India, Geological Survey of India and satellite images. Various thematic maps pertaining to slope, aspect, relative relief, drainage, geological structure and land-use/land-cover were generated with the help of ArcGIS 9.3 and ERDAS 9.3 software for Kullu valley. Global warming in high altitude area is likely to have effect on shrinking Glaciers in the Beas river basin and delve the pattern of geomorphological process on the topography of the high altitude mountain slopes, referring mountainous hazards impacts. We have also used the Peoples' perceptions methods through direct field observation. The village level data on various issues have been collected through fieldwork in the study area. It includes the participant observation, direct observation (self-assessment), and photographic assessment. We examined the traditional and local or indigenous techniques for hazards assessments in Kullu Valley following methods given in Table 1. Practical measurement and identification of hazards such as landslides, rock fall, debris-flow, floods, mudflow, avalanche etc. and the perceptions of local community regarding various issues and their responses, and mode of adjustment through questionnaires were subjected to study.

\section{Results and Discussion}

There is no doubt that the Himalayan watershed has undergone a most dynamic change in land-use owing to 
Table 1 Traditional and Local or Indigenous Techniques/ methods for Hazards Assessment

Air photo interpretation and photogrammetry

Traditionally very useful for preliminary assessments, to confirm field evidence and to assess remote areas. Data and sequential photos may be useful in change detection and chronology development.

Use of local and/or indigenous knowledge in inhabited regions, gathered in the field

May be useful in hazard site identification, chronicling of past events, their impacts and characteristics, and identification of useful adjustments and preventive measures.

Use of historical documents, maps, photos, newspapers, travellers' and surveyors' diaries and notebooks, books, reports and papers, all usually in library and archival sources

Very important source of general information on an area and its conditions but rarely used by scientists, may be useful in describing and chronicling past hazard events, must be used with care.

Adapted from Gardner and Saczuk (2004)

the rapid increase in population. Some land-use activities, such as cutting of trees for timber, which leads to deforestation, may increase the frequency, magnitude and spatial extent of some of these hazardous processes. Subsequently, natural hazards cause a great deal of harm and damage every year and have generally increased over the last decade.

\section{Topography}

Lower slopes of Kullu valley, Himachal Pradesh, India has a relatively low gradient, covered by para-glacial debris-flow and alluvial fans and terraces (Owen et al. 1995). The lower slopes created an inland topographical oasis of relatively flatland that was readily and effectively used for settlement and agriculture within the otherwise very rugged terrain of the south slope of the Lesser Himalaya. Geological aspects of Kullu valley is of vital importance not only to understand structures, rock formations and the evolution of landforms but also to investigate the mineral deposits, constructions of dams, diversion tunnels, harnessing hydro power, developing geothermal power etc (Singh, 1998). It helps understand the nature of slope for a sound determination of road building alignments and mountain hazards susceptibility. The rocky hill slopes form a straight inclination of 30$40^{\circ}$. In the upper catchment area, the slopes are steep ranging between 35 and $40^{\circ}$. Hard rock formations cover hilly and mountainous terrain mainly comprises of igneous and metamorphic rocks belonging to the Jutogh, Shali/Largi and Shimla groups and occupies the major part of the area in the northern, central and eastern part. Granite and gneisses are intruded in the meta-sediments of Shali/Largi and Shimla groups. In the western and southern part sediments comprising sandstone, shale, siltstone, conglomerate etc. of Dharamshala/Sabathu group and Siwallik group of Tertiary age are observed.
Alluvium, terrace deposits, fluvial deposits of Quaternary period occur in the intermontane valleys (Bahl valley, Sarkaghat valley etc.), and constitute an important geological formation (Fig. 4, Geology, Lesser Himalaya).

\section{Hazards in Kullu valley, Himachal Pradesh, India}

The main course of the river Beas flow approximately 100 kms from north to south across the Lesser Himalayan ranges. The climate of the valley is strongly influenced by summer monsoon and winter incursions of cold air masses and westerly storms, which may bring heavy snowfall. Throughout the year and at higher elevations, the area is subject to occasional extreme snowfall and blizzards. The summer monsoon brings copious and sometimes intense, rainfall more than $1000 \mathrm{~mm}$ (Fig. 5, Rainfall Trend). The area has been subjected to extreme and damaging meteorological/hydrological events such as floods, blizzards, snow avalanches, and debris torrents, as well as landslides and earthquakes, throughout it.

Owing to its typical geomorphic setting, high relief variations, dominant impact of monsoon winds, thick forest cover, presence of glacier and glacial lakes along the higher reaches, the Beas River is prone to various types of natural hazards. Prevalent hazards are cloudbursts, flash floods, forest fires, landslides and mass movement. The snow avalanches are also common along the higher reaches, but the damages caused by them are trivial as they occur at distant from human settlements.

\section{Cloudbursts in Himachal Pradesh, Western Himalaya, India}

Out of 36 cloudburst events recorded in Himachal Pradesh, India during 1990-2014, 15 (41.7 \%) were reported only from Kullu valley. This indicates that the valley is more prone to cloudbursts (Table 2, Fig. 6). Spatial distribution of flash flood and cloud burst show that Kullu valley is particularly in high risk of cloudbursts in upper catchment areas. The quick impact of cloudbursts was high river discharge and erosion. The erosion of its banks caused substantial losses of property and even life. Cloudbursts were usually common during the monsoon period between late June and early September and were restricted to headwater area (Beas River) of the closed tributary valleys. Occasional cloudbursts in June were related to the early approach of monsoon, while the events in September were related with the extension of monsoon. It is a new terrible hazard which came into existence since last decade (Bhan et al, 2004). The people in the villages of Solang, Kothi, Palchan, Ruwar, Majhajh and Kulang (upper villages) are scared with cloudburst in the sense that land, forest and human as well as animal lives were completely destroyed and washed away by cloudburst in 2010-2012. Cloudburst took place twice particularly in the Solang village. Besides livestock and human beings, dense forest and orchard areas along the river 


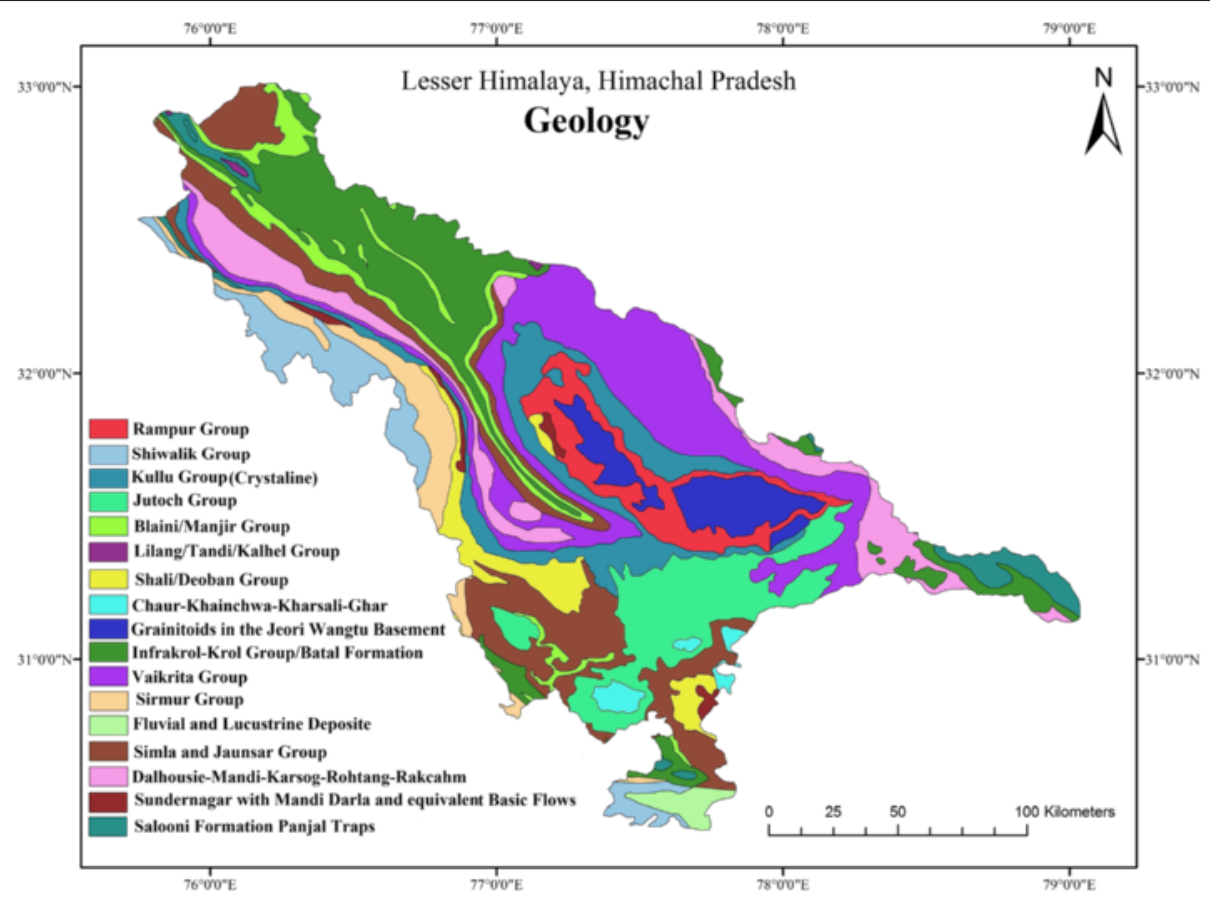

Fig. 4 Geology, Kullu Valley, Himachal Pradesh; Source: NATMO, 2014

Solang was damaged. More than five ha land was washed away killing five people in the Solang village recently during monsoon in 2014. While in the another event more than 100 acre land and many lives were washed away at Shot Village in Parvati Valley in July 2014.
An extensive damage was also recorded due to cloudburst at Gojra village near Naggar in 2013. The high rate of cloudburst events in Kullu valley was connected with the geomorphic conditions, i.e., high relief, closed basin morphology and high temperature gradients that create

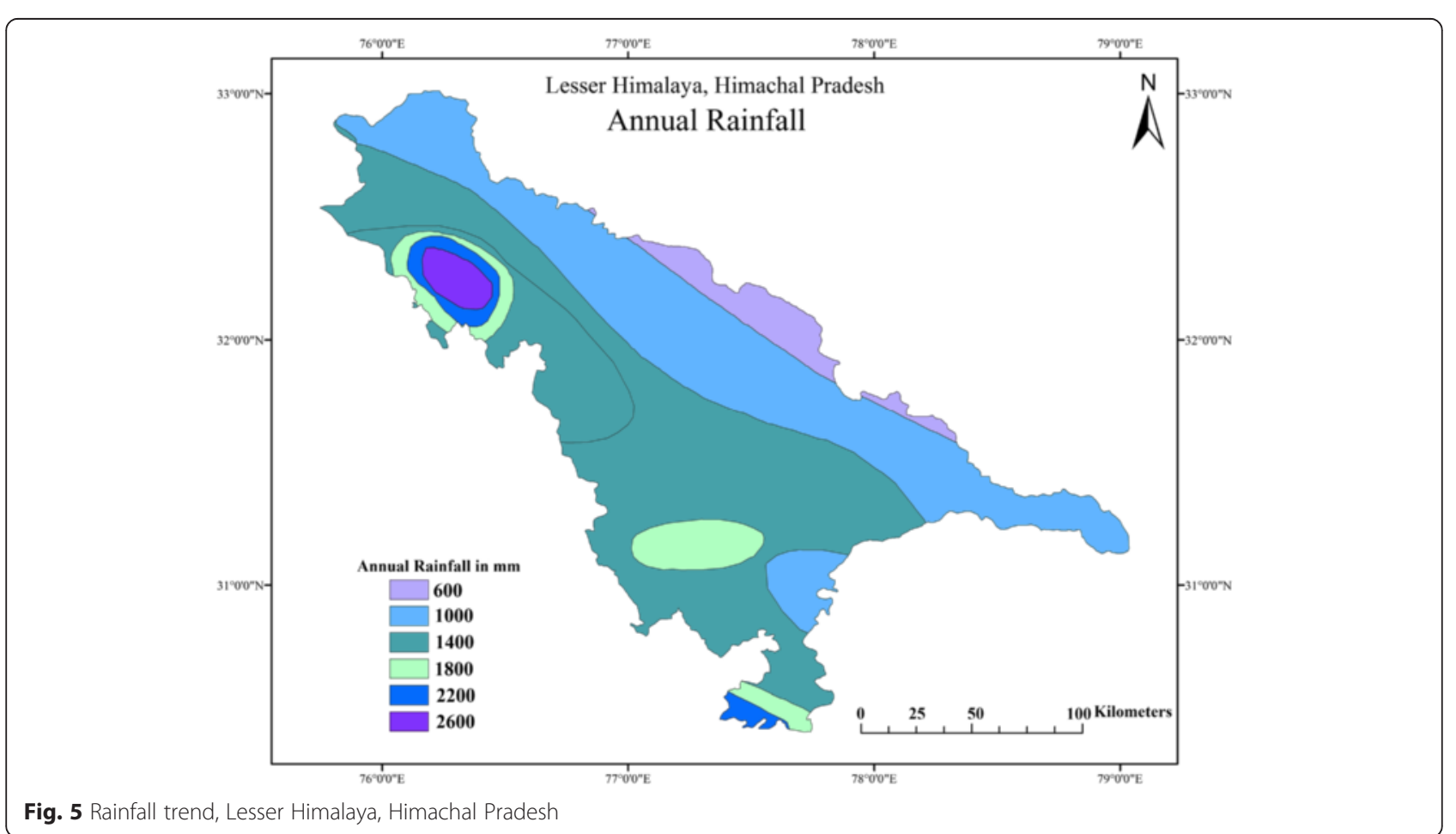


Table 2 Spatial Distribution of Cloud burst in Himachal Pradesh

\begin{tabular}{|c|c|c|c|c|c|c|c|c|}
\hline District & June & July & August & Sept. & Total percentage & Average & Cloudburst probability & Risk category \\
\hline Kullu & 2 & 4 & 7 & 2 & 15 & 1.25 & $>1 /$ Year & Very High \\
\hline Shimla & 1 & 1 & 4 & 0 & $6(16.7)$ & 0.5 & 1 in 2 Year & High \\
\hline Kinnaur & 0 & 2 & 2 & 0 & $4(11.1)$ & 0.33 & 1 in 3 & High \\
\hline Mandi & 0 & 2 & 1 & 0 & $3(8.3)$ & 0.25 & 1 in 4 & High \\
\hline Kangra & 0 & 2 & 0 & 0 & $2(5.5)$ & 0.17 & 1 in 6 & Moderate \\
\hline Chamba & 0 & 0 & 2 & 0 & $2(5.5)$ & 0.17 & 1 in 6 & Moderate \\
\hline Sirmaur & 0 & 0 & 1 & 0 & $1(2.8)$ & 0.084 & 1 in 12 & Low \\
\hline Solan & 0 & 0 & 1 & 0 & $1(2.8)$ & 0.084 & 1 in 12 & Low \\
\hline Lahul and Spiti & 0 & 1 & 0 & 0 & $1(2.8)$ & 0.084 & 1 in 12 & Low \\
\hline HamirPur & 0 & 0 & 0 & 1 & $1(2.8)$ & 0.084 & 1 in 12 & Low \\
\hline Bilaspur & 0 & 0 & 0 & 0 & 0 & 0 & & Low \\
\hline Una & 0 & 0 & 0 & 0 & 0 & 0 & & Low \\
\hline Total & 3 & 12 & 18 & 3 & $36(100)$ & & & \\
\hline
\end{tabular}

Source: Revenue Department, Himachal Pradesh and Himachal Pradesh State Disasters Management Authority, Shimla, Himachal Pradesh 2014 Compiled by Researcher

localized cloud concentration and convectional cyclone formation. The confined nature of tributary basins and high mountain ranges along the periphery provides appropriate geomorphic conditions for cloudburst phenomenon in Kullu valley.

Flash floods in Kullu valley, Himachal Pradesh, India Series of flash floods in 1902, 1945, 1988, 1993, 1995, 2000 and 2003 were important in inferring the severity of seasonal flash floods in Kullu valley. Data shows that the recurrence was accelerated and short-spanned, consistent to the observations of (Sah and Mazari 2004). This clearly indicates a rapid environmental change in recent decades. The flash floods were also correlated to extreme rainfall and occasional cloudburst events during monsoon from mid-July to mid-September. The 1995 flash flood caused massive landslide at Luggar Bhatti near Kullu, Himachal Pradesh collapsed 65 persons

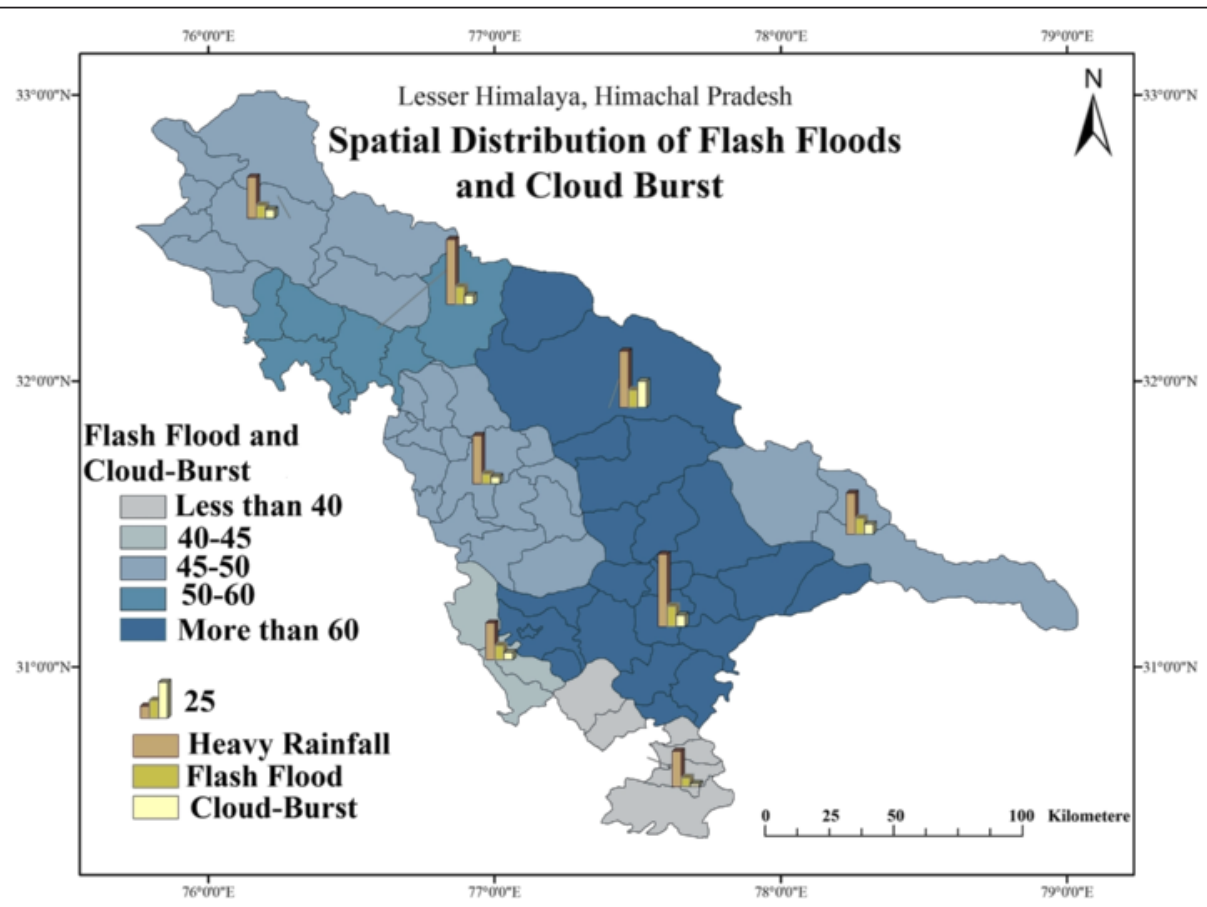

Fig. 6 Spatial distribution of flash flood and cloud-burst; Sources: Indian Meteorological Department (IMD) Centre, Shimla 
including heavy property damages, overturning a suspension bridge and eroding bridge abutment (Sah and Mazari 1998). Earlier in 1993, flash floods affected the town of Manali, India where massive bank erosion and flood water damaged many buildings and roads. The recent cloudbursts occurring on July 16 and August 7, 2003 in Pulia Nal (Sah and Mazari 2004) and Solang Nala washed away 38 and 40 workers of the Parvati Hydro Project and Rohtang Tunnel Project, respectively.

Forest fires in Himachal Pradesh, Western Himalaya, India The third important environmental problem in Kullu Valley, Himachal Pradesh, India was forest fire, a matter of concern to the people and the local administration. Participatory methods helped conclude that forest fires led huge loss of vegetation cover and soil erosion on the valley slopes in 1910, 1915, 1921, 1929, 1931, 1946, 1952, 1965 and 1970. Their spatial distribution in Kullu Valley has been a major hazard susceptibility issue since 2006 (Fig. 7, Density of forest fire). The wild fire of 1921 damaged the high altitude fir forest in the valley (Walia 1994). Soil erosion was accounted due to increased periodic forest fires. Massive alluvial fans, terraces, etc. are confined to the valley bottom. Occasional forest fires are also the one of the environmental hazards in the Valley.

The area of Upper Beas Basin is also highly vulnerable to fire hazard. The potential for a major fire hazard depends upon the characteristics of the fuel, the climate and fire behaviors. Forest fire as a hazard is usually evaluated in terms of loss of life, property damage (burning of buildings or complete (settlements), and the loss in timber. Both the types of fires hazard are found in the Upper Beas Basin, Lesser Himalaya. Considering the historical prognostication of the fire hazard in the Upper Beas Basin, it is found that a several incidents of forest fire as well as fire in the settlements have been recorded. The forest region of Upper Beas Basin is less vulnerable to fire hazard as compared to Garhwal Himalaya. But increasing recreation in the forest, overgrazing and other anthropogenic activities in the forests of Upper Beas Basin are increasing the probability of risk of forest fire hazard.

\section{Landslides/mass movements in Kullu Valley, Himachal Pradesh, India}

It is interesting to note that no major slope failures in the form of landslides have been observed on the hill slopes except in the periglacial zone in the upper catchment area and higher altitude zone elsewhere in Kullu Valley. Landslides and mass movements were mainly restricted to non-cohesive quaternary material and usually took place during the monsoon period when slopes get wet and at saturation point give way to slides and other forms of erosion. River banks in the alluvial fan-terrace zone undergo severe toe erosion during periodic high discharge conditions affected by extremely high rainfall and/or cloudburst events in the catchment area. This particular type of mass movement results in severe damage to property and also led to loss of human lives as a consequence. The most part of the district is mountainous terrain with the main ranges of mountains running

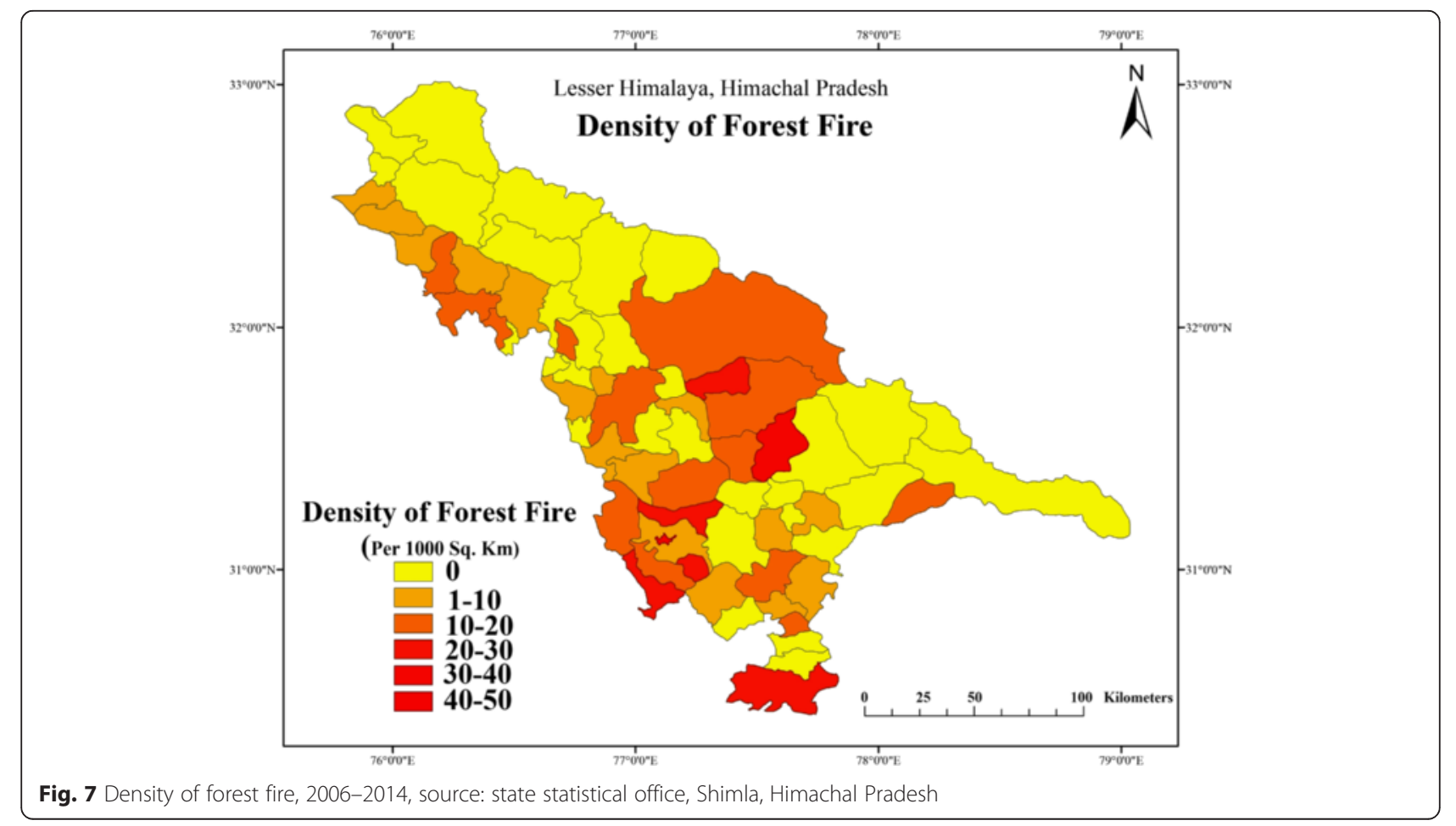


from the north to the south with the system being broken up by innumerable transverse spurs. The most conspicuous is the Jalori range which is crossed by a high altitude road from Kullu to Shimla by a pass named as Jalori passes (Fig. 8, Physiographic Map). The district has two major river systems namely Satluj and the Beas and on its northern slopes is unusually well covered with deodar (Cedrus deodara) and blue pine (Pinus wallichiana) forests of great value. North of the Beas River is the Nargu range, a continuation of the Bir Bhangal, separating Mandi from Kullu and crossed by the Bhubu pass $(2889.5 \mathrm{~m})$. The mountains elevation here varies upto $3963 \mathrm{~m}$ and the slopes often being very precipitous while the valleys are deep (Singh and Haigh 1995). Almost parallel and running down the centre of the district is the Ghoghar-ki-Dhar of which the slopes are fairly gentle. It is not well covered with vegetation, but covered of excellent grazing land and the salt quarries of Drang and Gumma.

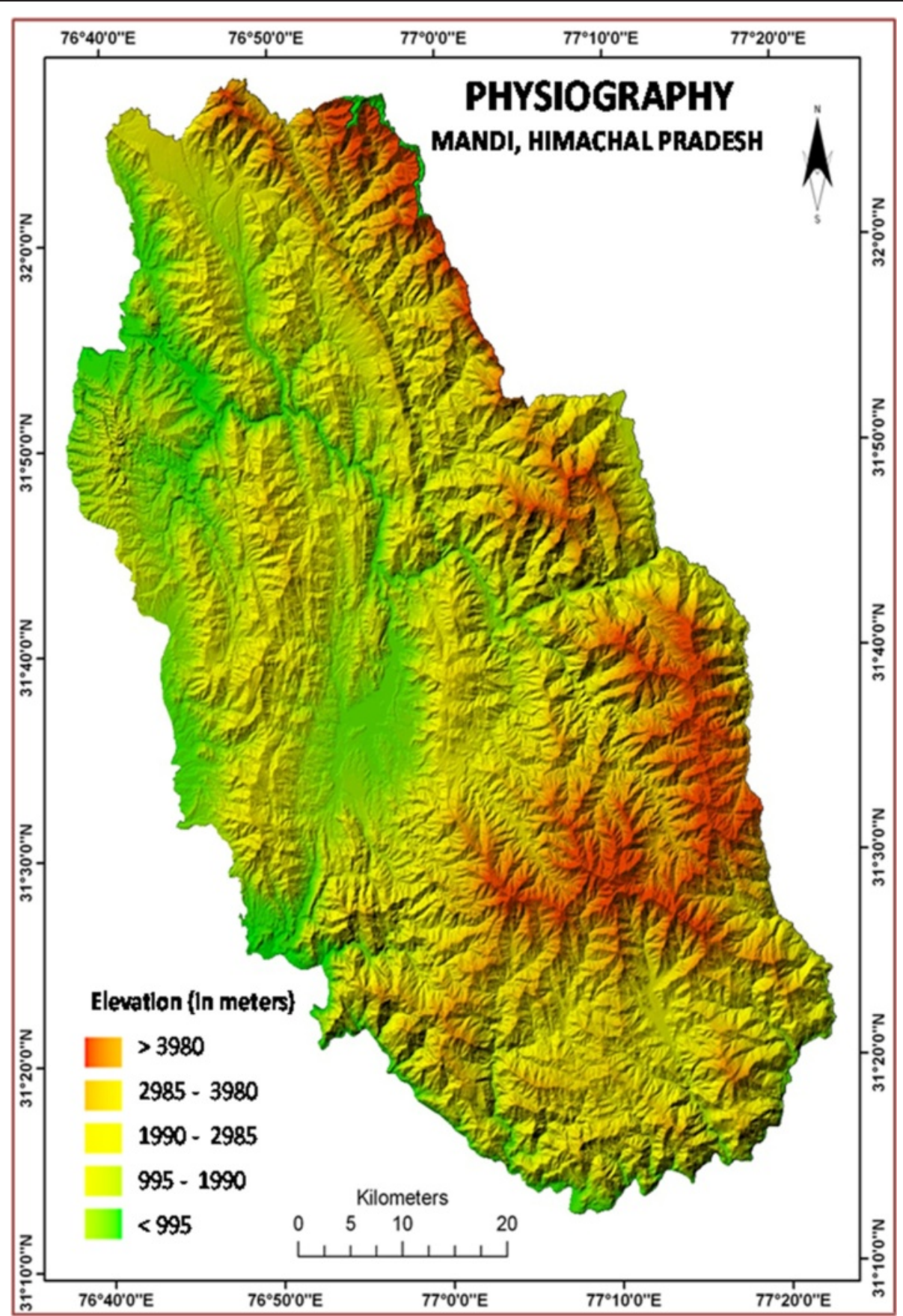

Fig. 8 Physiographic map, Mandi, Himachal Pradesh, source: landsat satellite image 
Landslide is a complex geodynamic phenomenon. It is directly depends on the local geo-environmental setting. It is varies over time and space. In the study area two sets of landslides has been categorized. A landslide has occurred in both sides such as along road and other, away from roads. It was noted that most of the landslides has occurred on human modified landscape. Some of the major causes are:

1. Slope cutting and excavation for the various development works such as road, settlement, dams, tunnels etc. It was noted that older road section of national highway are somewhat stabilized and the more vulnerability of phenomenon is noticed along the newly constructed state highways and major districts roads. Due to slope excavation these are exposed to processes of erosion and frequent landslides occurs often induced by rainfall and seismic events. The road section between Sunder Nagar to Aut is almost stabilized. There are some landslides on this stretch which fails frequently such as one is chosen for geo-technical investigation six $\mathrm{km}$ from Pandoh towards Kullu. The vulnerable road sections to landslides are Churag-Kalanagar stretch on SH-13, Jogindernagar-Sarkaghat (MDR) Ner Chouk to Jhanjheli MDR-25 etc.

2. Slope under cutting by streams are the other cause of landslides along streams. Small streams and rivulets become torrential during monsoon season with enormously increased erosion and transportation capacity.

3. Land-use practices are also affecting slope instability, these are a few but frequently landslides occur near the cultivated land.

4. Deforestation of slopes causes bare slope exposed to erosional processes rain water infiltrate in to slope and causes failures.

5. Prolong spells of rainfall.

6. Seismic events.

Unplanned slope cutting for the construction of road is the most important factor responsible for landslide and soil erosion. Mass wasting hazard prevails almost all the road sector in the Upper Beas Basin. The areas between Manali to Palchan and Manali to Kullu are most vulnerable to soil erosion. Once, the slope is disturbed for construction of road, monsoon washed away the soil along With the gravel and other materials. Finally the landslides become a common feature of such areas. Because of increasing intensity of soil erosion due to monsoonal rainfall and seepage of water the slope is ultimately converted into large-scale mass wasting hazard. Now situation has been converted into grim intensity of soil erosion and now rill and gullies formation have fully developed. Also the accumulation of debris on the road has become a serious threat to the transportation. Hundreds of such types of spots have been identified in the $52 \mathrm{~km}$ stretch of Upper Beas Basin, between Aleo to Rohtang Pass.

\section{Perceptions Regarding Causes of Hazards, Kullu Valley, Himachal Pradesh, India}

Household level attitudes and perceptions against causes of hazards were collected for individual hazards: their root cause and other responsible factors were pinpointed through questionnaires. Deforestation, slope cutting and heavy rainfall were key driving factors causing several hazards particularly soil erosion, landslides and rock fall. Except for fire hazard, all hazards are equally important and triggered by both anthropogenic and natural causes. Slope cutting for the construction of roads, deforestation and lack of drainage technique were the basic factors identified for the origin of rock fall. Overgrazing, heavy rainfall and tourism were identified as other responsible factors for rock fall hazards. Slope cutting and construction activities, lack of drainage techniques and overgrazing were important as associate factors for soil erosion. About 72 respondents recognized the faulty agricultural practices as a tool for soil erosion hazard (Table 3, Additional file 1). Slope cutting, construction activity and overgrazing were others important factors as indicated responsible for the origin of the soil erosion hazards by 195 respondents.

\section{Peoples' perceptions about trend of Hazards in Lesser Himalaya, Himachal Pradesh}

Intensity level of different hazards is not always uniform. Hazards are caused due to change in geophysical set up. The scale of severity is based on state of fragility and vulnerability. As far as the frequency of hazards in the Upper Beas Basin is concerned it can be seen from Table 4 that the trend and frequency have been categorized under 6 headings for easy interpretation, namely: increasing rapidly, increasing slowly, constant, reducing rapidly reducing slowly and don't know. The hazards of landslides, floods and cloudbursts have been regarded by the respondents as increasing rapidly over time by $80,93.5$ and $65 \%$ respectively. Rock fall hazard was the least in mention (Table 4, Additional file 2). Landslide, Flash floods, and cloudburst are major problem in Kullu valley.

\section{Peoples' perceptions about aspects of hazards and techniques of control/magnitude the Hazards, Western Himalaya, Himachal Pradesh}

Indigenous knowledge is often hailed for its versatility to recognize and respond to the livelihood changes (Turner and Clifton 2009) but it has also been transformed by ecological and socio-cultural changes (Pirker et al. 2012). 
Table 3 Peoples' Perceptions Regarding Origin of Hazards

\begin{tabular}{|c|c|c|c|c|c|c|c|c|}
\hline Hazards/Causes & Landslide & Floods & Avalanche & Cloudburst & Fire & Rock fall & Soil erosion & Total \\
\hline 1. Deforestation & 5 & 5 & 3 & 4 & 0 & 4 & 5 & 26 \\
\hline 2. Slope cutting and construction of Roads & 5 & 0 & 1 & 0 & 0 & 4 & 5 & 15 \\
\hline 3. Improper Draining on slopes & 3 & 1 & 0 & 0 & 0 & 2 & 5 & 11 \\
\hline 4. Overgrazing & 3 & 0 & 0 & 0 & - & 3 & 4 & 10 \\
\hline 5. Steep Slopes & 2 & 1 & 4 & 0 & 0 & 2 & 3 & 12 \\
\hline 6. Heavy Snowfall & 0 & 1 & 5 & 0 & 0 & 1 & 1 & 8 \\
\hline 7. Glacial Lake Outburst & 0 & 1 & 1 & 0 & 0 & 1 & 0 & 3 \\
\hline 8. Heavy Rainfall & 5 & 5 & 2 & 3 & 0 & 1 & 4 & 20 \\
\hline 9. Changing Land-uses & 2 & 1 & 1 & 2 & 0 & 1 & 2 & 9 \\
\hline 10. Tourism & 2 & 1 & 1 & 1 & 3 & 2 & 1 & 10 \\
\hline 11. Faulty Agricultural Practices & 1 & 1 & 1 & 1 & 1 & 0 & 2 & 7 \\
\hline Total & 28 & 17 & 19 & 11 & 4 & 21 & 32 & \\
\hline
\end{tabular}

Source: Primary Survey, 2014

Compilation by Researcher

The local community utilizes indigenous skill or knowledge for the purpose of hazard control and in mitigation techniques to reduce the risk somewhat. The technical expertise, economic status and awareness level are important tools through which one can assess the status of a community. There are certain numbers of hazards, which can't be checked completely but undoubtedly their risk and intensity may be reduced considerably by advanced technical know-how and efficiency in preparedness. Table 5 is an attempt to understand and analyze the level of awareness and technical expertise of the local community of the Upper Beas Basin to mitigate the different kinds of hazards. Every individual hazard has been analyzed in relation to its most effective controlling technique (Additional file 3).

The control over deforestation and launching afforestation programme on a large scale were the two most preferred remedies or techniques, which have an impact on almost every category of hazards. Better drainage technique, control on overgrazing and over urban sprawl and tourism, embankments on the riversides are other highly favored hazard control techniques replied by a large section of the respondents. Apart from control over deforestation and afforestation techniques, the construction of dams and reservoirs and embankments to riversides are the most important techniques responded by 183 and 173 respondents respectively.

Afforestation, embankment, better drainage techniques on slope, check on urban sprawl, and ecotourism are effective techniques used for hazard prevention and mitigations. These are the best local techniques to control and mitigate landslide and soil erosion hazards. The other techniques may be derived by the active participation of community in the hazard monitoring and mitigation programme:-

(1) Community participation increases the success rate of hazard mitigation programme.

(2) The participation of local community enhances the effectiveness of implementation of hazard prevention schemes and makes them more disseminated and recognized.

(3) Peoples' participation motivated the local community to critically analyses the impact of hazard on their lives.

(4) Participation assures the mental preparedness of the local community to cope with hazard occurrences.

Table 4 Peoples' Perception Regarding Present Trends of Hazards (Frequency), Kullu Valley, HimachalPradesh

\begin{tabular}{|c|c|c|c|c|c|c|c|}
\hline Trend & Landslide & Floods & Avalanche & Cloudburst & Fire & Rock fall & Soil Erosion \\
\hline Increasing rapidly & 4 & 5 & 1 & 3 & 1 & 1 & 1 \\
\hline Increasing slowly & 1 & 1 & 1 & 2 & 2 & 3 & 2 \\
\hline Constant & 1 & 0 & 2 & 0 & 3 & 1 & 3 \\
\hline Reducing rapidly & 0 & 0 & 1 & 0 & 1 & 1 & 1 \\
\hline Reducing slowly & 0 & 0 & 2 & 0 & 1 & 1 & 1 \\
\hline Don't Know & 1 & 0 & 1 & 1 & 1 & 1 & 1 \\
\hline
\end{tabular}

Source: Primary Survey, 2014, Compilation by Researcher 
Table 5 Peoples' Perception Regarding Techniques of Control/magnitude the Hazards

\begin{tabular}{|c|c|c|c|c|c|c|c|}
\hline Techniques & Landslides & Floods & Avalanche & Cloudburst & Fire & Rock fall & Soil Erosion \\
\hline 1. Afforestation & 5 & 5 & 5 & 5 & 1 & 5 & 5 \\
\hline 2. Control over deforestation & 5 & 5 & 5 & 5 & 2 & 5 & 5 \\
\hline 3. Construction of dam and Reservoirs & 0 & 5 & 0 & 1 & 0 & 0 & 0 \\
\hline 4. Embankments & 3 & 5 & 0 & 1 & 0 & 0 & 5 \\
\hline 5. Control on overgrazing & 4 & 1 & 1 & 0 & 0 & 3 & 3 \\
\hline 6. Better drainage techniques on Slope (along the road) & 5 & 0 & 0 & 0 & 0 & 2 & 5 \\
\hline 7. Agro- forestry & 1 & 1 & 1 & 1 & 1 & 1 & 3 \\
\hline 8. Control on construction of houses in the vulnerable area & 1 & 2 & 1 & 1 & 3 & 1 & 1 \\
\hline 9. Better agricultural practices & 0 & 0 & 0 & 1 & 0 & 0 & 1 \\
\hline 10. Slope-based construction & 5 & 0 & 0 & 0 & 0 & 5 & 3 \\
\hline 11. Check on Urban sprawl/tourism & 3 & 1 & 1 & 3 & 5 & 4 & 5 \\
\hline
\end{tabular}

Source: Primary Survey, 2014

(5) Participation ensures that things are done in the right way, for both the pre and post disaster managements.

(6) Participation helps in utilizing and incorporating valuable indigenous knowledge of the people.

(7) Participation develops a sense of self-reliance in the local community and encourages indigenous methods and skills to mitigate the impact of hazards.

(8) Participation makes people more conscious about the causes and effects of hazards and makes them more informative regarding preventive measures to be taken to safeguard their lives and resources.

\section{Tourism and environmental degradation, Himachal Pradesh, India}

The influx of tourists in Kullu Valley, Himachal Pradesh, India has increased in multiple phases increasing from 13,310 in $1979-80$ to 67,132 in $1991-92$. This figure further rose up to 1, 20,867 in 1996. Earlier the majority of tourists were domestic but now the influx of foreign tourists is steadily growing in Upper Kullu Valley, Himachal Pradesh. The total number of foreign tourists increased from 9,757 in 1989-12,910 in 1991-92 and 32,204 in 1996 (Table 6).

Maximum number of domestic visitors to Kullu Valley was recorded in months of June and May (Figure 9). The growth of tourism and the process of urbanization can go hand in hand. The infrastructure required to provide basic amenities to the tourists accelerates the process of urbanization. Although the settlement pattern in the valley is linear along the slopes of the Beas Basin, the town of Manali located at the headwater has developed as the epicenter for the growth of tourism and the urbanization in Kullu Valley induced by it. The growth in urban population has increased from $15.89 \%$ in 1961 to $40 \%$ in 1991. There has been a dramatic rise in the number of hotels and guesthouses between 1975 and 1996 their number has gone up from 2 to 640 in and around Manali. However, the valley was in trouble in environmental hygiene and managing the solid wastes due to tourism.

The influx tourist to the Kullu Valley has disturbed its splendid environment. The numbers of vehicle increased from 82 in 1869-2, 85,333 in 2012. The number of vehicle increased during the tourist season, shattering the serenity and calm of the areas. The developmental activity related to urbanization has also increased simultaneously.

We can promote ecotourism for sustainable development. Ecotourism is a form of tourism based on the natural ecological attractions of a destination area. It differs from mass tourism by having a lower impact on the environment and by requiring limited infrastructure development. A few positive initiatives relating to tourism and other development processes which may be considered for the study area are sanitation and sewage facilities in the town of Manali, Kullu and Bhuntar and water treatment plants in private hotels to create awareness among the rural masses regarding sanitation and hygienic. Ecotourism stresses the need to conserve the natural environment, thus offer an opportunity to capitalize on underdeveloped natural attractions without incurring the adverse effects of conventional mass tourism.

\section{Livelihood security options in Lesser Himalaya, Himachal Pradesh}

The anthropogenic activities, economic growth, unplanned haphazard growth of the tourism and urban agglomerations have degraded not only the local environment but also have reduced the natural resources base of the transhumance communities. Apart from above, the anti-ecological approaches of the government particularly "Natural Land Act, 
Table 6 Numbers of the Tourists in Kullu Valley in Himachal Pradesh

\begin{tabular}{|c|c|c|c|c|c|}
\hline Year & Total & Domestic Tourist No & Percent & Foreign Tourist No & Percent \\
\hline 1975 & 11062 & 10497 & 94.9 & 565 & 5.1 \\
\hline 1976 & 14477 & 13779 & 95 & 698 & 5 \\
\hline 1977 & 15792 & 14718 & 93.2 & 1074 & 6.8 \\
\hline 1978 & 11033 & 10239 & 93 & 764 & 7 \\
\hline 1979 & 13310 & 12519 & 94 & 791 & 6 \\
\hline 1980 & 15306 & 14235 & 93 & 1074 & 7 \\
\hline 1985 & 22959 & 19974 & 87 & 2985 & 13 \\
\hline 1987 & 48744 & 41366 & 84.9 & 7378 & 15.1 \\
\hline 1988 & 52745 & 44261 & 83.9 & 8484 & 16.1 \\
\hline 1989 & 57116 & 47359 & 82.9 & 9757 & 17.1 \\
\hline 1990 & 61596 & 50675 & 82.3 & 10921 & 17.7 \\
\hline 1991 & 67132 & 54222 & 80.8 & 12910 & 19.2 \\
\hline 2001 & 158867 & 106663 & 67.1 & 52204 & 32 \\
\hline 2012 & 285593 & 195847 & 68.5 & 89746 & 31.43 \\
\hline
\end{tabular}

Source: Department of Tourism, Shimla, Himachal Pradesh, 2014

1986" (distribution of land to the landless people) in which the forest land (thatches) were redistributed to the landless communities of lesser Himalaya, Himachal Pradesh. Since, the Kullu Valley is more fertile with green lush forests which attracted maximum number of the new settlers from Lahul, Spiti and other peripheral areas. To concentration of migrated population led to deforestation for agriculture, later to horticulture and now to tourism and recreation. Consequently, a large number of thatches have now disappeared leaving behind the livelihood crisis to the local communities of the transhumance. Hence, new dimension have emerged between economic and ecology, dependency and selfreliance. An urgent and immediate actions and remedies have become the need of the time to save livelihood resources base of the local community and to save the geo-ecology of the Beas basin, Lesser Himalaya, Himachal Pradesh.

The sustainable livelihood security of such region may best be achieved by enhanced land-uses aided by technologies of bio-engineering and small scale engineering involving the renaturalisation of degraded mountain geosystem. Taking the ecosystem approach and evaluating the interactions between atmospheric, biological, physical and anthropogenic components the mitigation measures may be investigated. Local knowledge systems have a vital role to play in the implementation of land resources management policies. Uses of Remote Sensing data, supplemented by Geographical Information System (GIS), will enhance the techniques of hazard mitigation particularly monitoring and forecasting of hazards. Land-use planning through the

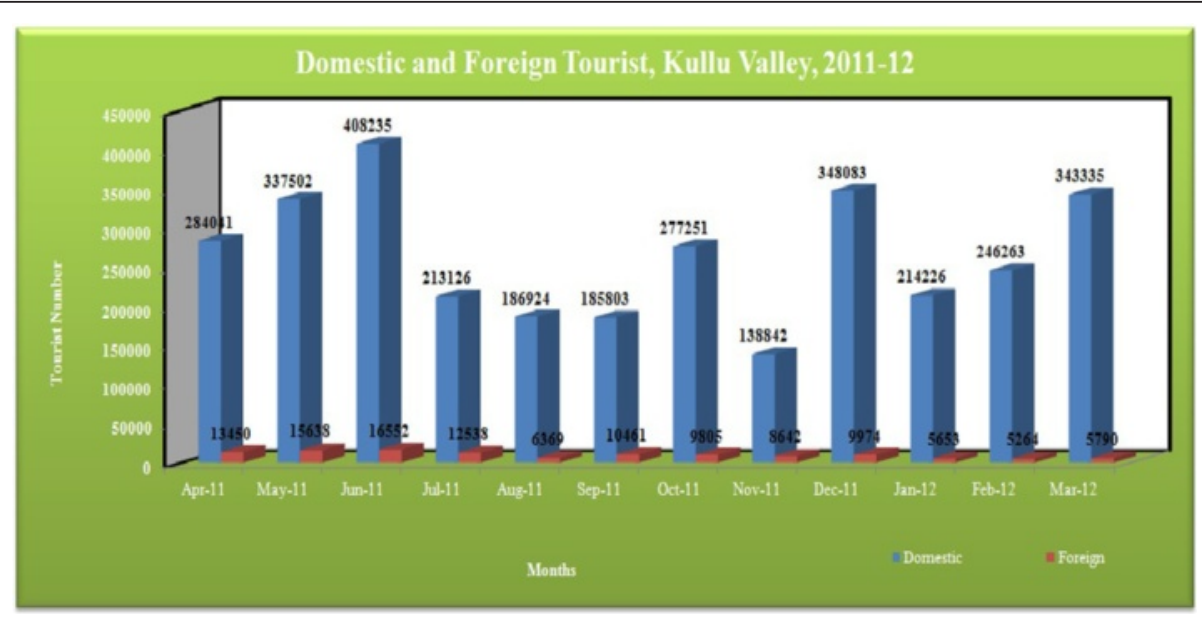

Fig. 9 Monthly wise domestic and foreign tourist, Kullu Valley, Source: Ministry of Tourism (Market Research Division) Government of India 
inculcation of hazard zone mapping may prove an effective tool for enhancement of land-uses and prevention from hazards by reducing the probability of risk. The conclusion that is offered is the suggestion that minimum human intervention should be allowed arid that such fragile geo-ecological cultural entities should be preserved under carrying capacity criteria consideration of the resources. Enhanced land-use capability, however, can reduce the vulnerability of the region. Among the natural resources available in the study area, Common Resources (CRs) and Common Property Resources (CPRs) such as forests, pasture land, river etc. have a good say for livelihood of the local community. Therefore, understanding of development policies conducive to the promotion of economic activities compatible with land capability and sustainability should be disseminated among the society for environmental sustainability and livelihood security in the region.

Hazards cannot be avoided, however their disastrous consequences can be minimized through proactive use of a variety of planning measures, support infrastructure and implementation of risk transfer mechanism. Capacity building of government (Policy planner and implementation) and policy maker about climate adaptation and disaster risk reduction strategies and Policies, Citizen engaging process and participatory approaches. Also, their sensitization about changing definition of governance and citizen participations in policy is essential aspects. The development and compliance of specific guideline for engaging citizen in policy process should be integral part of all the policies and departmental meeting. In each department-responsible for formulation and implementation of climate adaptation and disaster risk reduction policy an executive board comprising of representatives of various stakeholders, including NGOs, private sector, industries, institutions, public organizations and awareness etc. should be involved (Jafer 2013).

\section{Conclusion}

We have demonstrated that a significant part of Kullu Valley is subject to soil erosion and landslides. The escalation of risks and vulnerability has come about through population growth and land-use intensification in the areas, both of which have encroached upon hazard zones and in some case, such as road construction on slopes, have exacerbated the hazard of slope failure. The association of deforestation, rainfall and steep topography was augmentative. Therefore, the continued careful site identification, mapping, monitoring and mitigation were found imperative. Mountains have ecological, recreational, educational and scientific values, which need to be utilized in a sustainable way. In addition, for the sustainable development, environmental issues must take second place to economic priorities. The following steps should be considered:

$>$ Control on the numbers of tourist in the Kullu and Manali area by opening new tourist centre in the others parts of the Lesser Himalaya.

$>$ Restriction on the overuse of polythene bags in the areas so that water pollution in the river can be checked.

$>$ Checking the further transformation of land from agriculture to non-agriculture uses.

$>$ Restricting agriculture to slope less than $15^{\circ}$ so that hydrological potential can be maintained or more should be stopped and should be planted with trees. $>$ Agronomic experiments with the object of identifying cropping systems and rotations which are harmless to the ecology and environment of the valley should be initiated.

$>$ Minimize damage to local vegetation through selection of appropriate construction planning and practices.

$>$ Existing trails, temples, resting places, water taps, springs etc. should not be disturbed and a step should be taken to integrate these with the constructed road when possible

$>$ Review issues and opportunities for increasing off-farm incomes in the rural areas.

$>$ Carry out planning and feasibility studies to assess specific opportunities.

$>$ Develop government and non-government approaches to support investments in rural industries including crafts, tourism, rural enterprises in Kullu, Manali, Mandi and Lahul \& Spiti.

$>$ Afforestation, timber distribution, grazing, fuel wood, watershed management, and forest harvesting in lesser Himalaya

$>$ Now following new directions to support

community needs and conservation.

Mountains have ecological, recreational, educational and scientific values, which need to be utilized in a sustainable way. There are a number of strategies we have developed based on integration of tourism, environmental hygiene and sustainable development. Promotion of offfarm activities was a significant buffer against climate change. Generation of employment opportunities through environmental protection and community development instituting public private partnership was a big hope of win-win situation.

Hazards cannot be avoided, however their disastrous consequences can be minimized through pro-active use of a variety of planning measures, support infrastructure and implementation of risk transfer mechanism. Natural hazard risks in the Kullu Valley, Himachal Pradesh has increased as a consequence of forest degradation and 
intensive land-use pressures. Building of hotels and construction of roads for tourist needs, haphazard construction are the primary factors in increasing the exposure to risk. These extreme events lead to disastrous effects and disturb the lives of people living in the vicinity. Vulnerability to natural disasters depends on both natural and social conditions and is affected by preparedness and mitigation efforts for extreme natural events.

Eco-development is an approach to economic development which is environmentally sound and ecologically harmonious for sustainable development in Himalaya regions. Science and technology has a great role to play in increasing resource productivity a necessary condition for attaining sustainable eco-development. The other crucial factors in sustainable eco-development are the people, their local level organizations and their qualities of leadership in involving people and ensuring their participations. The last but not the least is public policy and public invention. The laws in resource management should be enabling, and their enforcement should be strict. Lastly, the people, the human resource for which eco-education in resource management at the village level is very important.

\section{Additional files}

Additional file 1: Peoples' Perceptions Regarding Origin of Hazards. (XLSX $11 \mathrm{~kb}$ )

Additional file 2: Peoples' Perceptions Regarding Present Trend of Hazards (frequency), Kullu Valley, Himachal Pradesh, India. (XLSX 11 kb)

Additional file 3: Peoples' Perception Regarding Techniques of Control/ Magnitude the Hazards. (XLSX $12 \mathrm{~kb}$ )

\section{Competing interests}

The authors declare that they have no competing interests.

\section{Authors' contributions}

ASP Conception and design, acquisition of data through Primary Survey, Preparation of Maps and analysis, and Revise the manuscript. BWP Conception and design, acquisition of data through Primary Survey and final approval of the version. WL Drafting of Manuscript and Data Analysis. RMK Drafting of Manuscript, Revise the manuscript and Data Analysis. All authors read and approved the final manuscript.

\section{Authors' Information}

Mr. Abhay Shankar Prasad received his M.Phil degree in Geography from Department of Geography, Delhi School of Economics, University of Delhi and doing PhD in Geography from Department of Geography, Delhi School of Economics, University of Delhi, India. He has received Financial Grant from Climate Service Centre 2.0/Helmholtz-ZentrumGeesthacht, Germany, for Td Training Module that prepares researchers and practitioners for transdisciplinary research at the science society interface and Special Training Module on Mutual Learning in urban climate change adaptation, 2014. He is working on River basin management and livelihood security in Garhwal Himalaya.

Dr. B. W. Pandey is currently Associate Professor of Geography at Department of Geography, Delhi School of Economics, University of Delhi, India. He has received Shastri Fellowship of Canadian International Development Agency (CIDA) for the project on Hazard Zone Mapping in Himachal Himalaya and British Columbia, Canada in 1995. He has to his credit NASA (USA) Financial Grant for Global Land Use Project 2010. Dr.
Pandey has specialization in Mountain Environment, Natural Resources Management and Hazard-risk and Vulnerability assessment and Disaster Management.

Prof. Walter Leimgruber is currently Professor Emeritus in Human Geography, Department of Geoscience, University of Fribourg, Switzerland. Dr. Leimgruber has specialization in Political boundaries and trans-border issues, Cultural limits and questions of identity, Marginality and marginal regions, Processes behind human decisions and actions concerning environment and society.

Mr. Ripu M. Kunwar received his M.A in Geography from Florida Atlantic University, US. Currently he is $\mathrm{PhD}$ research scholar at Department of Geosciences, Florida Atlantic University. His research focuses on spatial, ecological and sociocultural ethnobotany of Byans Valley. He has received grants from ASC Fellowship, WLBC, USA, Rufford Small Grant, Rufford Foundation, United Kingdom, and GRIP Research Grant: Florida Atlantic University to undertake the research.

\section{Acknowledgements}

The authors are thankful to Dr. R.B. Singh, Vice-president, International Geographical Union (IGU) and Head of Department, Department of Geography. University of Delhi, India and Ratan Tata Library, Delhi School of Economics, University of Delhi for providing GIS Lab and library facilities in the Department.

\section{Author details}

${ }^{1}$ Department of Geography, Delhi School of Economics, University of Delhi, New Delhi, India. ${ }^{2}$ Department of Geoscience, Unit of Geography, University of Fribourg, Fribourg, Switzerland. ${ }^{3}$ Department of Geosciences, Florida Atlantic University, Boca Raton, USA.

Received: 1 July 2015 Accepted: 22 February 2016

Published online: 29 February 2016

\section{References}

Bhan, S.C., S. Paul, and K.L. Kharbanda. 2004. Cloudburst in Himachal Pradesh. IMD NewDelhi Publication 55(4): 712-713.

Bhasin, R., E. Grimstad, J.O. Larsen, A.K. Dhawan, R. Singh, S.K. Verma, and K. Venkatachalam. 2002. Landslide hazards and mitigation measures at Gangtok, Sikkim Himalaya. Engineering Geology 64(4): 351-368.

Burrard, S.G., and H.H. Hayden. 1933. A sketches of geography and geology of the Himalaya Mountains and Tibet-Part II.. Delhi.

Chambers, R., and G. Conway. 1992. Sustainable rural livelihoods: practical concepts for the 21st century, Rep. No. 296. Brighton: IDS.

Eriksen, S.H., and K. O'Brien. 2007. Vulnerability, poverty and the need for sustainable adaptation measures. Climatology Policy 7: 337-352.

Gardner, J.S. 2002. Natural hazards risk in the Kullu district, Himachal Pradesh, India. Geographical Review 92(2): 282-306.

Gardner, J.S., and E. Saczuk. 2004. Systems for hazards identification in high mountain areas: An example from the Kullu district, Western Himalaya. Journal of Mountain Science 1(2): 115-127. http://link.springer.com/article/10. 1007\%2FBF02919334.

Hahn, M.B., A.M. Riederer, and S.O. Foster. 2009. The livelihood vulnerability index: A pragmatic approach to assessing risks from climate variability and change - A case study in Mozambique. Global Environmental Change 19(1): 74-88. doi:10.1016/j.gloenvcha.2008.11.002.

Huq, S. 2007. Community-based adaptation: an IIED Briefing. London: International Institute for Environment and Development.

Jafer, E. 2013. Overcoming Roadblocks to Hazards, Vulnerability and Capacity Assessment in Urban India. In New Dimension of Disaster Management: In India, PP- 275-281, ed. A. Mishra. India: Serial Publication, New Delhi.

Jodha, N.S. 2005. Adaptation strategies against growing environmental and social vulnerabilities in mountain areas. Himalayan Journal of Sciences 3(5): 33-42.

Lemos, M.C., E. Boyd, E.L. Tompkins, H. Osbahr, and D. Liverman. 2007. Developing adaptation and adapting development. Ecology Society 12: 1-26.

Likert, R. 1932. A Technique for the Measurement of Attitudes. Archives of Psychology 140: 1-55.

NATMO, National Atlas and Thematic Mapping Organisation, Department of Science \& Technology. 2014. Calcutta, India.

Nibanupudi, H.K., and R. Shaw. 2015. Mountain hazard and disaster risk reduction. Japan: Springer. ISBN 978-4-431-55241-3. 
Ostrom, E. 2007. A diagnostic approach for going beyond panaceas. Proceeding National Academic Science USA 104: 15181-15187.

Owen, L.A., M.C. Sharma, and R. Bigwood. 1995. Mass movement hazard in the Garhwal Himalaya: In geomorphology and land management in a changing environment, edited by DFM McGregor and DA Thompson, 69-88. London and New York: Wiley.

Paavola, J., and W.N. Adger. 2005. Fair Adaptation to Climate Change. Ecological Economics 56: 594-609. doi:10.1016/j.ecolecon.2005.03.015.

Pandey, B.W. 2002. Geo-environmental hazards in Himalaya: assessment and mapping. New Delhi: Mittal publication.

Pandey, B.W. 2010. Hazard ecology: approaches and techniques. New Delhi: Mittal publication.

Pandey, B.W. 2014. Dynamics of Land-Use Change, Sustainability and Management, ISBN No- 978-93-5171-016-5. India: Press Research of.

Pandey, B.W., and A.B. Prasad. 2014. Land-Use Pattern and Hazards Risk Assessment in Kullu Valley, along the Beas River in Western Himalaya. Journal of Water \& Land-Use Management 14(1): 1-15.

Pirker, H., R. Haselmair, E. Kuhn, C. Schunko, and C.R. Vogl. 2012. Transformation of traditional knowledge of medicinal plants: the case of Tyroleans (Austria) who migrated to Australia, Brazil and Peru. Journal of Ethnobiology and Ethnomedicine 8: 44.

Punjab Government. 1926. Punjab district gazetteers, VII Part (A), Kangra District 1924-25. Lahore: Government, Punjab, India.

Ratz, T. 2000. Residents perception of the socio-culturalmimpacts of tourism at the Lake Balaton, Hungary. In. Richards G, Hall DR (eds.), 36-47. London, UK: Tourism and Sustainable Community Development. Routledge.

Rawat, P. 2013. GIS modelling on mountain geodiversity and its hydrological resources; in view of climate change. Saarbrücken: Lambert Academic Publishing.

Rawat, P.K., and C.C. Pant. 2007. Geo-hydrology of Dabka watershed, using remote sensing and GIS in management strategy for the Indian Himalayan development and conservation, eds. Pratap: Rawat MMS.

Rawat, P.K., P.C. Tiwari, C.C. Pant, A.K. Sharma, and P.D. Pant. 2010. Modelling of stream runoff and sediment output for erosion hazard assessment in lesser Himalaya; Need for sustainable land-use plane using remote sensing and GIS: A case study. Natural Hazards 59(3): 1277-1297.

Rawat, P.K., C.C. Pant, P.C. Tiwari, P.D. Pant, and A.K. Sharma. 2012. Spatial variability assessment of river-line floods and flash floods in Himalaya: A case study using GIS. Disaster Prevention and Management: An International Journal 21(2): 135-159.

Sah, M.P., and R.K. Mazari. 1998. Anthropogenically accelerated mass movement in the Kullu valley, Himachal Pradesh, India. Geomorphology 26: 123-138.

Sah, M.P., and R.K. Mazari. 2004. WIHG Annual Report 2003-2004: 16-17.

Sharma, P. 1998. Environment, culture, economy and tourism; dilemmas in the Hindu Kush-Himalayas.

Sinclair, A.J., and L.H. Ham. 2000. Household adaptive strategies: Shaping livelihood security in the western Himalaya. Canadian Journal of Development Studies 21: 89-112.

Singh, T.V. 1989. The Kullu Valley: Impact of tourism development in the mountain areas. New Delhi: Himalayan books, centre books for tourism research, Lucknow, India.

Singh, R.B. 1998. Land-use/cover changes, extreme events and eco-hydrological responses in the Himalayan region. In Sustainable development of mountain environment in India and Canada, ed. R.B. Singh, 53-67. New Delhi: Oxford and IBH Publishing Co.

Singh, R.B., and M.J. Haigh (eds.). 1995. Sustainable reconstruction of highlands and headwater regions. New Delhi: Oxford and IBH Publication.

Smit, B., and O. Pilifosova. 2001. Adaptation to climate change in the context of sustainable development and equity. In Climate Change 2001: impacts, adaptation and vulnerability, ed. J. McCarthy, O.F. Canziani, N.F. Leary, D.J. Dokken, and K.S. White, 876-912. Contribution of Working Group II to the Third Assessment Report of the Intergovernmental Panel on Climate Change: Cambridge University Press, Cambridge.

Turner, N.J., and H. Clifton. 2009. It's so different today: climate change and indigenous life ways in British Columbia, Canada. Global Environmental Change 19(2): 80-190.

Walia, J.S. 1994. Revised working plan for the forests of Kullu and Parbati forest division. Government of Himachal Pradesh, India: Forest department.

Wisner, B. 2010. Climate change and cultural diversity. International Social Science Journal 61: 131-140.

\section{Submit your manuscript to a SpringerOpen ${ }^{\circ}$ journal and benefit from:}

- Convenient online submission

- Rigorous peer review

- Immediate publication on acceptance

- Open access: articles freely available online

- High visibility within the field

- Retaining the copyright to your article

Submit your next manuscript at $\boldsymbol{s p r i n g e r o p e n . c o m ~}$ 